\title{
Sexual Identity and Transformation at a South African University
}

\author{
Mary Hames
}

\section{Abstract}

Despite the proliferation of policies ostensibly protecting all persons' rights, and mounting critical academic debate and scholarship on sexuality and sexual orientation, sexual orientation in the academy remains a site of deep contestation. The first section of this paper discusses the national legal framework as a basis from which the state's new social engineering uses liberal human rights as tools for the democratic transformation of society. In the second section, by focusing on the University of the Western Cape, my critique examines the persisting evidence of prejudice and homophobia in South African society alongside seemingly progressive policymaking and intellectual debate. I consider the centrality of national law and policymaking in the restructuring of the higher education environment and assess the extent to which the new education, labour, and other national policies and legislative measures substantively change the climate and culture of higher education institutions. In developing this critique, I map out some of the everyday struggles which may often be marginalised by an overemphasis on national and institutional policymaking for change.

This paper questions the dominant rhetoric of 'campus citizenship for all' in postapartheid South Africa by critiquing the state's role in setting agendas for higher education policy design and implementation. Historically the state has always played a 
pivotal role in both national and higher education policy design. Currently the state has also become the custodian of gender and race transformation. How, then, do civil society structures and educational institutions respond to and implement these topdown policies?

Many policy analysts (Shaw, 2004; Unterhalter, 2000; Coffey and Delamont, 2000) contend that policies are never valueneutral. The massive growth and range of policies in the higher education sector suggests that South African policymaking is obviously value-laden. It appears squarely to address the rights of groups previously marginalised on the basis of race, gender, and sexual orientation. But what can be said about the implicit values of these policies, about their covert biases and their neglect of homosexuals' substantive rights and needs in higher education institutions?

The first section of the paper reflects on the development processes of the national policy and legal framework. A connection is made between the activist and academic involvement in the initial policy design and the subsequent codifying of relevant legislation by the state. The second part of the discussion uses the opportunities and challenges within a specific institution as examples of making the policy framework living documents.

\section{The national policy and legal framework}

Given South Africa's apartheid legacy, the policymaking and legal reconstruction by the postapartheid state has been preoccupied with the eradication of race and gender discrimination in all spheres. Quantitative targets and punitive measures have been legislated in order to redress past imbalances in the state, academic, and private sectors. Other 
discriminatory practices, related to, for example, same-sex orientation and disability did not receive as much attention and activists for these concerns still consistently lobby and advocate for the recognition of their rights. Yet, there is the widespread popular perception that South Africa has systematically addressed the concerns of those citizens who were excluded in the former dispensation, including gays and lesbians (Oswin, 2005: 580). This discussion will interrogate this perception.

Post-apartheid South Africa experienced an unprecedented flood of legislative and policy measures in an effort to ensure that all discriminatory practices relating to race and gender equity were properly addressed in both work and civil society spaces. These policy and legislative measures were not created in a vacuum but have a very specific context. Sheila Meintjes (2005:260) speaks about the South African vision for a gender equal society that was embedded in the social and political movements (the women's and gay and lesbian movements, the civic organisations, the trade unions, and the liberation movements) which formed the crucible of the new democracy.

It is therefore not because of the benevolence of the state that the 1996 Constitution ensconces these progressive human rights as primary concerns; activism by civil society contributed pivotally to the formation of the liberal state laws. The National Coalition for Gay and Lesbian Equality, for instance, lobbied consistently and actively for the support and patronage of prominent African National Congress members for the inclusion of sexual orientation in the Constitution (Fester, 2006: 102). This kind of coalition politics, says Meintjes (2005: 261), opened spaces in the public arena for a more nuanced gendered understanding of citizens' rights, in an andocentric, heteronormative context. The incorporation of sexual orientation in the Constitution as a 
human rights concern was the result of a protracted negotiation process.

Article 9(3) of the Constitution, generally known as the Equality Clause, states that :

The State may not unfairly discriminate directly or indirectly against anyone on one or more grounds, including race, gender, sex, pregnancy, marital status, ethnic or social origin, colour, sexual orientation, age, disability, religion, conscience, belief, culture, language and birth.

The inclusion of sexual orientation in the range of rights concerns did not necessarily mean automatic equitable and substantive access to a variety of privileges normally bequeathed to full citizenship. In order for LGBT activists to gain access to numerous other entrenched rights they systematically litigated and mobilised so that their socio-economic and political rights, as well as their right to live with dignity as South African citizens, would be recognised in the eyes of the law and in broader society (Hames, 2003). For instance, protracted individual litigation, class action, and activism slowly ensured that the rights of LGBT people were included in the Labour Act (1995); the Employment Equity Act (1998); the Rental Housing Act (1999); and the Domestic Violence Act (1999). Sodomy was decriminalised. Same- sex couples were afforded the right to adopt, and more recently the right to same-sex 'marriage' albeit under the watered down Civil Union Act (2006) was recognised.

But legal recognition did not automatically translate into social acceptance. Prejudice, bias, and hatred remained to a large degree intact in all South African communities. The LGBT community still has to rely on the Constitutional Court for the protection of their dignity and identity. The Constitutional Court 
holds the vested power and authority to make groundbreaking decisions about the rights of LGBT people. Other constitutional mechanisms were also created to act as watchdogs and monitoring bodies to ensure gender equity and nondiscrimination. These Chapter Nine institutions include the Public Protector, the Human Rights Commission, and the Commission for Gender Equality. However, these constitutionally-created mechanisms proved to lack the power to ensure that gender inequalities and hate crimes are effectively eradicated (Hames, 2006: 1315).

Other subsequent provisions were created to fill the gap and on 16 June 2003 the Equality Courts were established. The purpose of these courts was to deal with allegations of unfair discrimination, harassment, and hate speech. These courts were established under the Promotion of Equality and Prevention of Unfair Discrimination Act (Act No. 4 of 2000) which is also referred to as the Equality Act. The significance of the Act lies in the fact that it was promulgated mainly to provide for the opportunity to litigate by the unemployed and members of the workforce that fall outside the ambit of the Employment Equity Act (EEA), as well as for those disputes that have not been provided for in the EEA, particularly 'hate speech' and 'harassment which is related to sex, gender or sexual orientation' (Equality for All, 2000: 3). Every High Court serves as Equality Court and some Magistrates' Courts are also designated as such. These courts are free, which the Constitutional Court is not.

Because of these policy and legislative developments, South Africa came to be perceived as the most gay-friendly, tolerant, sexually liberated democratic state on the African continent. However, the violence against and killing of Black lesbians, statements of homo-prejudice and homophobia by public 
figures, the backlash of the religious right, and a homophobic media show that South African society is still deeply conservative, divisive, patriarchal, homo-prejudiced, and racist.1

It is significant that the new laws and policies are also applicable to higher education institutions. The higher education environment, as an environment for shaping postapartheid knowledge and identities, was specifically targeted as a site for state transformation. The following section will look at the higher education environment and will explore its responses to the new state engineering of academic institutions. Emphasis will be placed on the fact that higher education institutions, far from being major change agents in society, are in fact sites of insidious conservatism around sexual orientation. This has also meant that they are currently spaces where every day acts of resistance offer the potential to drive much needed meaningful change and education restructuring, as the case study of UWC so clearly reveals.

\section{Equality in higher education institutions}

Higher education is a sector where civil society played a key role in postapartheid transformation (Badat, n.d.: 13-14). Since 1997 the education ministry has dominated the shaping of the higher education legislative framework.

Higher education, in particular, became a key site for the government's new social engineering. The new government inherited a deeply fragmented higher education environment that consisted of 36 tertiary education institutions. Each of these institutions was deeply embedded in its own apartheid legacy of complex interactions between state, race, gender, ethnicity, admission policy, location, institutional autonomy, language, class, and financial and human resources. The education 
ministry explicitly expressed its concern about the reluctance shown by many of these institutions to transform and stated that the transformation agenda should be 'radical and comprehensive' (National Plan for Higher Education, 2001). Statements in the National Plan included: 'The Ministry will not hesitate in certain limited circumstances to intervene directly in the higher education system in order to bring stability and sustainability' (Paragraph 1.5 on Steering Mechanisms). And, 'The Ministry will not... allow institutional autonomy to be used as a weapon to prevent change and transformation' (Paragraph 1.51 on Institutional Autonomy). These very direct statements stemmed from government's frustration that some institutions wanted to cling to their 'white privileged histories and positions'.

A plethora of policies, Green Papers, White Papers, and Higher Education Acts were produced between 1994 and 2003. These included the National Commission on Higher Education (1996); the White Paper (1997); the Higher Education Act (1997); and the National Plan for Higher Education (2001). This focus led to a quantitative increase of Black staff and students in historically white institutions (although a large percentage of senior staff at historically Black institutions remains made up of white heterosexual men). However, these measures took a very essentialist approach towards the concept of 'gender' in subscribing to a binary understanding of the definitions of men and women. They rarely made mention of the recognition of sexual orientation or sexual identities.

It was only the 1997 White Paper (Education White Paper 3, 1997) that specifically included 'sexual orientation' as a concern in the paragraph dealing with Institutional Culture. Section 3.42 of the White Paper reads: 
The Ministry proposes that all institutions of higher education should develop mechanisms which will:

Create a safe and secure campus environment that discourages harassment or any other hostile behaviour directed towards persons or groups on any grounds whatsoever, but particularly on grounds of age, colour, creed, disability, gender, marital status, national origin, race, language, or sexual orientation.

However, the status of 'sexual orientation' in subsequent documents suggests that sexual orientation in the 1997 White Paper was simply a token inclusion. The other policies and laws were not concerned with social justice per se, but with the development of a single higher education system. The priorities in the other documents were finance and human resources, and Badat (n.d.) argues that certain trade-offs had to be made. The question remains whether the exclusion of the clause on 'sexual orientation' in subsequent policy documents was one of the trade-offs. Higher education institutions began to concentrate on institutional recruitment and appointment policies that changed the race profile and monitored the quantitative increase of women, as opposed to the implementation of qualitative measures for staff and students who did not identify themselves as heterosexual women or men. Kraak (2001: 24) notes that the expressions of equity and redress in the policy and legislation were merely ameliorative and not substantive. Bernstein (2001) argues that since universities in particular are perceived as the shapers of critical intellectual thought and discourse, they form and influence public opinion, rather than merely transmit received knowledge. The expectation is therefore not unwarranted that the subsequent institutional policies would have made provision for broader and more inclusive diversity and equity than merely tinkering with race and gender quotas. 
Some researchers (Badat, n.d.; Fataar, n.d.; Kraak, 2001) also argue that the state's preoccupation with the higher education environment led to 'policy overload' or 'policy crowding'. The transformation agenda became saturated with discourses of efficiency, fiscal rectitude, quality assurance, performance indicators, and marginalisation, at the expense of the previous concern with equity (Fataar, n.d.: 6). Louise Morley (2005: 412) warns against the preoccupation with this new type of managerialism and quality. She says that this approach to higher education systems 'represent[s] an example of a modernist, rationalist construction of the universal subject, whereby teachers, researchers, managers and learners are constructed as disembodied, cognitive, socially decontextualised entities'. It is the disembodiment of those that do not identify with the hegemonic notion of heterosexuality within the academy that lies at the core of this discussion.

After 1997 there was an obvious omission or slippage of 'sexual orientation' in the policy documents. According to Marshall (1977: 1) 'policy slippage' takes place when the rhetoric of formal policy differs in reality from the actual implementation of the policy. Kraak (2001: 3) says that in the South African case the 'slippage' can be ascribed to the fact that 'policy doubt and retraction' took place once the limits of state power and the complexities of governance had begun to surface in the first few years of the new millennium.

Müller's (2000) argument is that institutions have choices in responding to state-initiated policies and can either actively and fully implement them in both the structure and culture; or can implement them reluctantly and still allow the powerful actors to prevent them from being effective; or even implement them with 
passive toleration and thus defeat the intention of the policy. Many institutions chose to implement policies selectively. Bennett (2005: 6) notes for instance that in some institutions the road to concrete policy ratification took several years.

If the state-engineered policies were actively and fully implemented by the higher education institutions this would have been reflected in numerous institutional policies. Physical structural amenities would also have been provided. These policies and amenities include: unisex toilets for transgender people; granting leave for gender reconstructive surgery; student housing that welcomes same-sex couples; including a nondiscrimination clause in its recruitment advertisements; the specific inclusion of same-sex orientation in all policies to make it easier for litigation and disciplinary purposes in instances of discrimination; the creation of safe and secure environments where same-sex loving people could freely socialise given the prevalence of homophobia and homoprejudice on campuses. The necessity of policy regulation with regard to sexual expression and identity in higher education rests on the assumption that it would be required to dismantle deep-seated and extremely intransigent gender hierarchies, prevent harassment, gender discrimination, and injustice.

It is against the backdrop of the policy reform that I go on to ascertain how state policy affected an already politicised and progressive institution, the University of the Western Cape.

\section{The University of the Western Cape: a case study}

In order to explain policy development at the University of the Western Cape (UWC) I draw loosely on a Foucauldian approach (Foucault, 1978), examining the history and social practices of the university to understand the past and current political 
discourses around gender, sexuality, and the formation of sexual identities in the institution.

UWC, located in Cape Town, is a historically Black University (HBU) situated in close proximity to two other universities, both historically white. UWC has a proud history of participating in the struggle for social justice and gender equity in the country. The institution is well known for its role in the eradication of apartheid. Its mission statement reflects the promise to 'seek racial and gender equality and contribute to helping the historically marginalized participate fully in the life of the nation' (Mission Statement, 2007). Given UWC's comprehensive focus on social justice, driven by committed institutional activism and struggles by staff and students, one can safely include 'same-sex orientation' in its definition of the 'marginalized'.

University policies in the early 1990 s were deeply embedded in the feminist principle that the personal is political. UWC has taken structural measures to combat discrimination on various levels including race, gender, sexual orientation, and non-sexist language. These include the formation of the Gender Equity Unit, whose functions include developing; monitoring, and reporting on, gender policies which specifically include 'reporting on sexual orientation', and a Gender Policy Action Committee (GPAC), which is a Senate/Council structure.

Many South African researchers (Fester, 2006; Meintjes, 2005; Walker, 1997; Badat, n.d.) note that progressive and inclusive policies were developed through activism. At UWC there were feminists and men who supported feminism who were involved in the shaping of various gender-sensitive policies. These activists were also involved in the broader anti-apartheid movement. Predominantly Black feminist intellectual activists 
challenged the discriminatory status quo on campus and pushed for equity for women as well as for the lesbian and gay campus community. Not only was this activism on campus influenced by the broader liberation struggle, the climate on campus was conducive to pushing for interventions that would bring justice to everybody irrespective of gender, race, or class. This was true even in the mid-1980s when the liberation struggle was focused on racial equality whilst gender equality was not an issue. UWC was well ahead of the times.

UWC's gender policies were developed outside of liberal state language and the then-current gender discourse. There were three policies that are of specific interest for this paper: the Gender Policy; the Sexual Harassment Policy, and the NonSexist Language Policy. While the Gender Policy is rather generic, it was the first of its kind in South Africa. The Sexual Harassment Policy on the other hand made specific reference to the harassment of lesbian and gay people and included a clause on sexual orientation, again, the first policy in any higher education institution in the country to mention same-sex orientation. Discrimination against same-sex sexual orientation, hate speech, and actions were seen as punishable offences.

The institutional Sexual Harassment Policy was groundbreaking in its definition of rape:

Rape is considered as a serious crime of violence and is broadly defined as a sexual invasion of the body by force, an incursion into the private, personal inner space, without consent, by any object or part of the body (Policy and Procedure on Sexual Harassment, 1995).

This definition goes well beyond the definition in the current Sexual Offences Act and is firmly informed by feminist 
knowledge of gender-based violence. UWC remains the only institution in the country where a male survivor can lay a complaint of rape against a male attacker, or where a woman can complain of rape when she has been digitally or anally assaulted (Hames, et al., 2005: 162).

One of the functions of the Gender Policy Action Committee is to monitor and report on issues of sexual orientation to Senate and Council. 'Gender' at UWC is therefore an inclusive concept and campus policies address the needs of the most marginalised groups, namely women, and make provision for the nondiscrimination against all gendered bodies. The activism for sexual rights on campus included and benefited both staff and students. This was made possible through the activism of a women's caucus and a women's student group, called Kopanang, which challenged the patriarchal attitudes, structures, and the prevalence of sexism amongst the student body.

The other tangible benefits for same-sex staff were in the form of housing subsidies, medical aid, pension, adoption policy, and maternity and paternity leave. While these benefits and privileges were never formally constituted in any documentation, staff and students could take recourse and lay complaints at the Gender Equity Unit if they had been discriminated against in any form whatsoever.

However, while the gender-related policies of UWC were developed and implemented well in advance of South Africa's current liberal state language and legislation, these policies currently can be regarded as outdated. They need to be reviewed (Hames, et al., 2005: 153). Policy review is necessary for various reasons, amongst them the changed national legal and policy frameworks; the influence of national and global activism for 
sexual rights; the impact of technology and new forms of harassment amongst the campus community; and continuous discriminatory practices and hate action against homosexuals on and off campus.

South African higher education institutions are highly sexualised, racialised, and gendered environments. Terry Barnes (n.d.) describes the gendered nature of the academic environments as spaces and places that are intricately marked with codes for man-as-thinker, man-as-aggressive- debater, man-as-athlete, boys-becoming-men, etc. The addition of women (and, I would add, those who identify themselves as homosexuals) to this men's club is thus not only a statistical, but also an extremely meaningful and symbolic, exercise.

The existing gender dynamic makes it especially conducive to sexual exploitation, flirting, opportunistic sexual relations, and sexual discrimination amongst the more powerful and those with less power. Yet there are relatively few policies, even at UWC, that effectively address these grey areas. Even the policies around workplace equity rarely include rights and claims to remedies with regard to the violation of the constitutionallyrecognised right to freedom from discrimination on the basis of sexual identity. I argue therefore that institutional policies with regard to social justice and equity for people who fall outside the heterosexual paradigm and heteronormative working, teaching, learning, and researching environment have increasingly been compromised and even exploited within the academic space.

As with any other higher education institution in South Africa, intersections of race, gender, class, ethnicity, language, and religion play a prominent role in the construction of institutional culture at UWC. In addition there are the complexities of a 
struggle history, the existence of advanced gender policies, and the compliance with postapartheid legislation and policies. Currently there are two sexual harassment policies that are being used interchangeably at UWC. The 1995 policy is mainly used for student disciplinary procedures while the Code of Good Practice on the Handling of Sexual Harassment Cases (Section 203[1] of the Labour Relations Act of 1995) is used for staff disciplinary action. The institutional 1995 policy was designed outside the current legalistic framework whilst the Code of Good Practice is based on a rights-based legal framework that underpins most recent policy (Hames, et al., 2005: 153). It is therefore very difficult to negotiate justice and redress in instances of harassment or discrimination when there is no coherent policy. The 'Code' subscribes minimum requirements and action in addressing harassment. The 1995 UWC policy, on the other hand, was specifically created to address the complexities within an academic environment. State policy-making is geared towards the eradication of a hostile working environment and does not address the intricacies of a learning environment. UWC's choice to deviate from its own progressive and inclusive policy now allows for the confusion of parallel procedures to exist.

At UWC there was a period of policy vacuum when the new state engineering demanded that all higher education institutions establish democratic mechanisms to ensure that racial and gender inequities be eradicated within a certain timeframe. It also happened at a time when feminist university staff left the institution to work for government, private, and other education sectors. At the same time some academics were retrenched and the administrative staff was offered voluntary severance packages. There was a lack of leadership and direction from the institution itself and much of the transformation was driven by external policy and legislation. 
The period of 'policy overload' in the higher education environment also affected the past progressive policy developments at UWC. Institutions were pressurised to report to both the Departments of Education and Labour about progress made in connection with their race and gender profiles. UWC had severe financial difficulties and was also involved in merging its Dental and Nursing Faculties with those of the University of Stellenbosch, with the result that broader gender concerns were placed on the backburner. Lawyers were contracted to overhaul existing policies. New senior staff were appointed and they had no institutional memory and lacked feminist policy discourse. Policy 'slippage' took place. The proposed new policies lacked nuances in understanding sexual discrimination and sexism, and responded in compliance with the new legislation in a minimalist fashion.

In what follows I will look at specific examples which draw attention to the need for revised policy making in challenging homophobia on campus. UWC remains richly endowed with resources such as gender-specific structures, activists, and academics who are committed to transformation, and the space to organise and challenge prejudices.

Certain developments took place during 2005/6 that forced the institution to revisit its position and policies with regard to homoprejudice. One development was the increasing complaints of students (and in one instant a parent) of intolerance with regard to their sexual preferences; a male student wanted the Gender Equity Unit (GEU) to intervene because a group of gay students felt unsafe and unwelcome at the residences, and lesbian students were threatened with corrective rape. None of these students wanted to lay formal complaints against their 
offenders and the staff at the GEU decided to commission research on the phenomenon of the corrective rape threats and the lack of safety and security at the residences so that empirical evidence could be garnered. At this point the GEU had partnered with activist organisations outside campus and became involved in the national lesbian and gay rights campaign and decided to bring the broader campaign to campus.

In 2005 Yvette Abrahams conducted the commissioned survey on the lives and experiences of lesbian and bisexual women on campus. The findings by Abrahams pointed to a discomfort and tension between the progressive policy creation and hostile institutional culture and attitudes. It was very difficult to get current undergraduate students to openly identify with their lesbian/ bisexual identities and she had to rely largely on postgraduate students and students who had already left the campus. The research also mentioned the hostility, misogyny, and patriarchal attitudes of the Student Representative Council and fundamentalist Christian organisations on campus that strongly discouraged women students from volunteering at the GEU and forming the UWC Women's Support Network in 2001, on the grounds that it would turn them into lesbians (Abrahams, n.d.: 10).

Abrahams's research is particularly relevant because it foregrounds, like others (Epstein, O'Flynn and Telford, 2003), the 'forced normalization of heterosexuality' within academic environments. Macgillivary (2000: 304) calls this 'heterologic' which means same-sex relationships are largely unacknowledged by the public at large, nor are they recognised in social institutions. The deafening silence of this absence of acknowledgement resounds within the passages of the ivory tower. Mandatory or compulsory heterosexuality, says Hill 
(1995: 146), does not even have to be expressed for it to be understood and accepted. He states that the language, thoughts, assumptions, and symbols of the dominant society encode heterosexuality. Heterosexism, according to him, is the subtle neglect, omission, distortion, and annihilation of lesbians, gay males, bisexuals, transsexuals, and the transgendered.

Abrahams powerfully raises the fact that lesbian and bisexual women have long tended to be silent about their sexual identity, and that the main reason for this is the prevalence of homophobia. She argues that homophobia takes on many forms. University years are the time when young people form identities. Peer pressure to be heterosexual and fear about identifying as a lesbian or bisexual make these women postpone embracing a sexual identity until they leave the academy. Abrahams also found that it is not unreasonable for these women to be secretive about their sexual preferences and identities because of the fear of being attacked, raped, or beaten up.

The positive findings of the research are that lesbians and bisexual students who had a stable and loving family background, who had good role-models for alternative sexualities in their homes and communities, and who had high degrees of self-esteem, were most able to withstand the pressure of heteronormativity.

Abrahams's research findings were instrumental to the planning of the Gender Equity Unit's Focus Week on Prejudice Reduction and Anti- Homophobia during May 2006. This event was partly funded by the rector of the institution and was actively sponsored by the Triangle Project and the Good Hope Metropolitan Community Church. A primary strategy of the Focus Week was to invite positive role models, 'out' and public 
lesbians and gay men, to speak at the week-long event. These speakers were representative of both the campus and the broader community. This located same-sex relationships and policy making within the academy, and questioned the commitment of the university to basic human rights for all.

The week also bridged the praxis of living, studying, teaching, and researching on campus with the theorisation and prevalent pedagogies in the classroom. It questioned the 'exotifying', 'othering', and 'objectifying' of homosexuality in classrooms and the confusion and trauma often caused to those lesbian and gay students and staff who felt that their intellects and lifestyles had been compromised or belittled. They experienced risk to their own safety, especially when they had not been public about their sexual orientation. They said that such practices endorsed the normalisation of heteronormativity and made their experiences deviant and the subject of spectacle. The Focus Week was an affirmative process which tried to debunk deep-seated stereotypes and myths about homosexuality.

The third important event on campus was a conference by the Department of Religion and Theology in partnership with the Gender Equity Unit, the Women's and Gender Studies Programme, and the Triangle Project. The conference took place on 4 August 2006 and was titled 'Revisiting Intimacy: The Challenge of Homosexual Relationships to Church and Society'. Its purpose was to create a platform for vigorous debate amongst the church community and society at large on aspects of inclusiveness, respect for difference, and tolerance. It looked at homosexuality through the lens of intimacy.

Shortly after the conference a group of Christian students marched on campus with placards reading: 'Homosexuality is a 
sin'. Ironically this protest took place on 9 August, National Women's Day. The day was also the fiftieth anniversary of the Women's March to Pretoria. It is therefore particularly sinister that this Day was used to highlight opposition to same-sex intimacy. The march was a significant visual indicator of the existence and influence of fundamentalist religious and faithbased reactionary forces which drive much of the university's student life outside the classroom. It was also an indicator of the levels of sexism and homophobia that exist on campus. In an effort to establish whether this action constituted hate speech, the Gender Equity Unit approached the Constitutional Law department at UWC, only to find out that the right to religious freedom is broad, and extremely difficult to litigate against. The march also raised questions about the mobilisation of the religious right on campus in their campaign against the same-sex marriage debate that gripped the imagination of the faith-based communities as well as a large part of the conservative and fundamentalist community.

In oral submissions to Parliament with regard to same-sex marriages, the Triangle Project (2006) and other LGBT organisations made it clear that caution should be exercised by government in allowing the religious right to derail and hijack the agenda and change the discourse of rights into a rhetoric of sin and redemption. The Triangle Project, the oldest lesbian, gay, bisexual, and transgender organisation in the country, explicitly applauded such leaders as Archbishop Emeritus Desmond Tutu of the Anglican Church, and Reverend Moqoba of the Methodist Church, who unequivocally support the democratic rights of same-sex couples. Both these churches have representation on campus. It should also be noted that Archbishop Tutu is the Chancellor of the University of the Western Cape. 
All of the above events pose important challenges to an institution such as UWC. On the one level they indicate the progressive nature and ethos of the university which provides both the intellectual and activist space for a diverse group of people. This includes the opportunity and space to claim the right to freedom of sexual orientation. On the other level it is forced to deal with the discomfort of fundamentalisms, righteous attitudes and behaviours that claim the rights to organise and protest, their religious right, and the right to freedom of speech. Whereas both the Focus Week and the conference sought to reduce intolerance and homo-prejudice, the findings of Abrahams's research, the subsequent protest march, and the discussions on the university intranet alerted the institution to the deep-seated homophobia and hatred towards homosexuals within the campus community. It also endorsed the prevalence of misogyny on campus alongside other forms of prejudice practiced through sexual and gender discrimination.

The Focus Week challenged the prevalence of homoprejudice and homophobia in the institutional and academic culture and advocated for greater respect for diversity in sexuality on campus. It advocated for a feminist approach in the teaching methodologies and pedagogies and the 'mainstreaming' of the teaching of sexualities. It also mooted for a greater political awareness of what it means to identify as a homosexual campus citizen.

Studies on sex, sexuality, and sexual orientation are offered in various humanities courses but they comprise to a large extent the theoretical objectification, pathologising, and exotification of the 'other'. 'While higher education programmes do provide space for gay and lesbian studies either within existing programmes or as separate subjects, education generally 
proceeds as if gays, lesbians, bisexual or transgender people are peripheral to the core business' (Epstein, et al., 2003: 3). The teaching remains implicitly reactionary and this conservatism is reflected in the institutional culture.

Bennett (2006: 69) refers to the opportunity that exists within the academic environment to deal with pedagogies of sexuality differently. Pedagogies, she argues, must prioritise the destabilisation of heternormativity, or as Achmat (1993: 108) contends, 'celebrate the rupture and discontinuity' of the heternormative hegemony. hooks (1994) calls it 'teaching to transgress'. Exploring new ways of teaching and awarenessraising in a young democracy still laden by an apartheid baggage of hatred, violence, and intolerance are indeed priorities in the academy.

Courses on sex, sexuality, and sexual orientation usually imply that the latter is homosexuality as if heterosexuality is not a sexual orientation (Epstein, O'Flynn and Telford, 2002: 3). The academy allows for the discussion of sex and sexuality within the safe confines of the classroom but to a large extent ignores the structural and symbolic impediments that exist for the practicing of homosexuality beyond the formal theorisation. The quality of life outside the intellectual physical classroom space does not reflect the reality of many staff and students on campus. I agree therefore with Leck (2000: 332) that 'those formal studies will neither explain nor will they sort out for young persons or for those who live around them the intensity of the feeling and meaning of pressures and confusion'. As I have suggested, they in fact often compound the struggles of lesbian and gay staff and students.

There are still factors that constitute legitimate barriers to the 
acceptance and inclusion of homosexuality without prejudice within the academic programme. These fundamental challenges include amongst others the heterosexist and heteronormative nature of the academic environment, the construction of race, and the location of UWC.

Historically universities have been created for men by men and the nature of the institutions has not changed in spite of the fact that more women students enter these institutions or that women are increasingly occupying senior positions. Affirmative action and equity policies and legislation demand that women should have a greater quantitative and qualitative presence in the academy. Nevertheless, the norms, practices, and masculinity of the organisational culture exclude women on a variety of levels (Smulders, 1998; Fogelberg, et al., 1999). In the majority of cases the men (or, indeed, women) who occupy leadership and management positions in academic institutions are seldom familiar with feminist discourse or equipped with the analytical framework to understand the conjunction of gender, power, and organisational culture (Walsh, 2002: 35). This environment makes it difficult for feminists to create alternative frameworks for the development of politicised programmes and policies and to do consciousness raising with regard to sexual diversity. In conceptualising this naturalising of patriarchy Desiree Lewis (2003: 4) writes that the patriarchal scripts of identity and culture are entrenched in the icons that give shape to our behavioural codes, our institutional cultures, the ostensibly natural conventions by which we live, work, and find pleasure'.

Bennett (2005: 18) refers to the 'policy richness' of the academic environment. From the moment a student applies for access till the time of graduation she/he is compelled to follow rules and 
regulations. Yet, there is a policy drought when sexual orientation has to be addressed. The binary approach to women and men on campus does not allow for the nuanced needs of lesbian, gay, and transgender people. When young people enter the university they are usually at the age of consent: they can vote, obtain a valid driver's license, marry, and open accounts. All of this takes place within the heterosexist paradigm. They enter into relationships, date, and flirt, and their behaviour is sanctioned as long as it is within the accepted heterosexual framework.

During the Focus Week, students who identified as homosexual referred to the hostile academic environment where it is extremely difficult for them to claim their inclusive 'campus citizenship' as they are too scared to flirt or start relationships. They develop intricate networks to make new friends. They are too scared to openly ask whether someone is lesbian or gay, and carefully regulate the routine forms of flirting that 'straight' students use. Eye contact or communal acquaintances are the means of starting new relationships. One lesbian student said that she was too afraid to go to the pub as she is always harassed and threatened because of her sexual orientation.

Same-sex flirting is seen as offensive and criminal especially when one person is perceived to be heterosexual. More often than not university officials do not know how to deal with the complaint. Yet heterosexual dating and flirting are seen as normal and accepted even when there is blatant sexism, abuse, or harassment. One can therefore assume that heterosexual relationships have been emphatically condoned by the university authorities. As Leck (2000: 342) observes, universities are spaces where the 'ritualistic performance of heterosexual privilege and heterosexual displays of courtship are embellished, 
protected and promoted'.

Although the Sexual Harassment Policy makes provision for complaints by homosexuals and invariably includes hate speech, there is hardly a complaint on homophobia or homo-prejudice. People informally mention how they have been treated but refuse to lay formal charges. As Bennett (2005: 15) claims, 'few people, especially those who are young, economically vulnerable or socially embattled, can tolerate the malevolent scrutiny (perhaps accompanied by direct threats of continued physical violence) of hostile or threatened patriarchal systems'. How much greater is the jeopardy for those who have to complain against the discrimination or harassment because of sexual orientation?

The following statements, made by staff in interviews, are examples of subjugation and internalised homophobia in which the message is clear that it is better to remain silent than claim the right to dignity and respect: 'They accept me as I am, nobody refers to my sexual orientation and I never mention it. It makes things so much easier'; 'They always giggle and laugh when I pass them. I sometimes hear them say derogatory things but I rather keep quiet'. These are but two examples of references to the homophobia on campus.

Previous research amongst staff (Hames, et al., 2005: 177) reiterated the prevalence of homophobia: 'When they make remarks about $\mathrm{X}$ in the tearoom, I laugh with them. I do not think that homosexuality is normal but as a manager I have to keep my feelings and opinions to myself. I have never intervened or corrected anyone when they make discriminatory remarks'. Another staff member remarked: 'In the past I have made jokes and passed remarks with the other staff members about it but 
now I reprimand them. Although I still think it [homosexuality] is wrong'. More recently another staff member referred to a colleague and said: ' $\mathrm{X}$ is $\mathrm{OK}$. He is gay but at least he is not a moffie'. The research findings of Abrahams are therefore as applicable to the attitudes and perceptions of staff as they are to students.

During the preparation of the Focus Week, students were randomly approached and asked about their feelings towards homosexuality on campus. The recorded comments included: 'Gays will contaminate the campus and they do not belong here'. And a common remark was: 'It is against the Bible'.

The LGB students said that it is easier for them to be accepted when they 'act straight'. To 'pass as heterosexual or straight' is often seen as a survival strategy (Abrahams, n.d.; Lugg, 2003; Sanelli and Perreault, 2001). However, says Lugg (2003: 105) 'to pass' is also inherently discriminatory, undermining personal integrity and autonomy while eroding and denying an individual's legal and political rights. Some of the lesbian and gay alumni suggested a separate Pink Alumni organisation where they could mentor and assist current students to become complete campus citizens without fear of rejection or reprisal.

Lesbian students, subjected to sexism, racism, homophobia, and gender violence, hide behind their silence and are therefore not afforded the same opportunity to enjoy the privileges of their heterosexual peers. Both lesbian and gay students also prefer to be informed about events and workshops by e-mail or text messaging as they prefer to remain 'invisible' on campus. Sanelli and Perreault (2001) see this closeted behaviour as a way to endure years of education in which there is a denial of an important part of students' identity. 
The physical and geographical location of the university as well as the racial demographics of the student population give a specific context to developments at UWC. UWC was created by the apartheid architects to educate and serve a specific 'race' group, the 'Coloureds'. Since the mid- 70s the university has followed an open admissions policy and allowed 'African' students to enroll in spite of the separate development policy of the apartheid regime. Currently, the student population is Black with less than $1 \%$ comprising white students. The university has been the only institution in the Western Cape to offer pharmacy for the last two decades. Yet, prospective white students from the Western Cape region preferred to enroll at historically white institutions in other provinces that offered pharmacy. Most recently, when the new higher education policy obligated the institution to merge its Dentistry and Nursing Faculties with the University of Stellenbosch, there was only a minimal increase in white student enrollment. Women students comprise $60 \%$ of the student population. The experiences of students, especially reports from lesbian students, reflect to a large extent what is happening in the townships and in rural South Africa. Students' personal networks are with Black lesbian and gay organisations and individuals. There is the awareness that to be Black and homosexual has a very specific context and is a struggle in South Africa. The teaching staff of the university remains to a large extent white, heterosexual, and male. In some of the departments there are only white males.

Geographically the university is very isolated from the city and is physically located in an industrial area, in close proximity to Black townships. Minibus taxis are the main mode of transport for students although there are other forms of public transport available such as trains and buses. However, the trains and buses 
have limited times in which they operate. Black lesbian students reported this type of transport can be extremely dangerous for them.

The university is also far away from any spaces where social activities take place. Cape Town is globally known as the 'gay capital' of the country. There are numerous gay clubs and bars; the Triangle Project is based there; Cape Town Gay Pride is hosted every year and so is the Mothercity Queer Project (MCQP) costume party; several inclusive and embracing faithbased organisations are also based in the city. These are but a few of the attractions available to the LGBT community.

However, many of the UWC LGB students indicated that they do not feel welcome in many of these places because they perceive them as racist. This is illustrated in the first ever case heard in the Equality Court concerning allegations of racism in a Cape Town gay club. The case was settled with the club and the two bouncers concerned were made to pay fines ('Race settlement confirmed by equality court', 2004). This case starkly discredits the perception that 'The location of a university in or near large urban centres with their networks of gay bars, clubs and other community contacts can provide queer students with greater access to friendship, a sense of community and sexual relationships. In this context, the "gay village" or "scene" can overtake the campus as the main site for social interaction' (Epstein, et al., 2003: 132).

To combat the fact that the larger social environment is indeed hostile towards them, UWC students decided to form their own organisation on campus. They named it Loud-Enuf and decided to challenge the homoprejudice on and off campus in a systematic way. They have organised social gatherings, arranged 
workshops around identity issues, networked with numerous national organisations, and produced a newsletter with the same name. For them the main purpose of the organisation is to call UWC 'home'. Loud-Enuf may just be the vehicle to revive students' involvement in activism and the pursuance of social justice.

\section{Conclusion}

I have argued that the tireless campaigning for sexual rights had its origins in the activist and liberation movements. These concerns became legal rights and government became the custodian for both gender and sex rights and dealt with the issue in a progressively technocratic and legalistic manner. This meant that the marginalised groups in society were nominally included in important laws and policies but that that the realisation of these citizen rights remained the sole responsibility of the activists. Activism for sexual rights is continuing. LGBT activists realise that in order for them to enjoy complete citizenship they have to systematically dismantle discriminatory laws and challenge the Constitutional Court to repeal offensive laws.

The state and its gender machinery have not been proactive in providing real citizenship for all. Many of the liberal rights remain paper rights. Sexual rights campaigns are also mainly sponsored and supported by funders and donors outside South Africa. As I have argued, rights are consistently contested and struggled for through organisations and moblisation by different stakeholders, as has been the case at UWC.

The agenda for sexuality-inclusive transformation in higher education is not as actively pursued as it is in civil society. Many of the higher education institutions, if not all, did not respond to the inclusion of sexual orientation in the 1997 White Paper. It is individuals in these organisations that are taking up the struggle 
for sexual rights within the heteronormative ivory towers, sometimes at great cost to themselves. Although policies in themselves do not mean that the culture of an institution will change, at least they will offer corrective recourse when discrimination takes place. My argument, therefore, is that policies should recognise the diversity and complexity of a campus community and address those specific needs.

The classroom also remains a contested terrain for sexual identities for both the lecturer and the student. Activism should not be seen as separate from intellectual discourse and should collectively challenge patriarchal and heternormative notions on campuses. History shows that the path to educational transformation lay with the collective efforts of academics and the liberation movement activists. I firmly believe it can be done again.

Mary Hames is the Gender Equity Officer at the University of the Western Cape.

\section{Note}

1 Homophobia was particularly displayed during the samesex marriage campaign in 2006. Various media reports reflected societal homoprejudice. See V. Reddy (2002) for an article probing hate speech in southern Africa.

\section{References}

Abrahams, Yvette. n.d. Why stop when we are winning? Meeting the needs of lesbian and bisexual women on UWC campus. 
Bellville: Gender Equity Unit, UWC, Unpublished report, 2005.

Achmat, Zackie. 1993. 'Apostles of civilized vice': 'immoral practices' and 'unnatural vice' in South African prisons and compounds, 1890-1920. Social Dynamics 19: 92-110.

Africa Eye. 2007. They wanted sex with a lesbian. http://www.24.com/news/?p=\&i=436660 Date accessed: 1 March 2007.

Badat, M.S. n. d. Transforming South African higher education, 1990-2003: Goals, policy initiatives and critical challenges and issues. Unpublished paper, 2003.

Barnes, Terry. n.d. Introductory presentation, and accompanying document, Gender and Institutional Culture in Five African Universities, first project workshop, 18-20 May, 2005, Cape Town: African Gender Institute, UCT.

Bennett, Jane. 2006. Rejecting roses: introductory notes on pedagogies and sexualities. Agenda 67: 68-79.

-- . 2005. Ed. Killing a Virus with Stones? Research on the Implementation of Policies Against Sexual Harassment in Southern African Higher Education. Cape Town: African Gender Institute, University of Cape Town.

Bernstein, B. 2001. Symbolic control: issues of empirical description of agencies and agents. International Journal of Social Research Methodology 4 (1): 21-33.

Coffey, Amanda and Sara Delamont. 2000. Feminism and the classroom teacher: research, praxis and pedagogy. New York: 
Routledge.

Education White Paper 3: A programme for the transformation of higher education. 1997. Pretoria: Department of Education (GN 1196 of 1997).

Epstein, Debbie, Sarah O'Flynn, and David Telford. 2003. Silenced Sexualities in Schools and Universities. Stoke on Trent, UK and Sterling, USA: Trentham Books.

Equality for All. 2000. Promotion of Equality and Prevention of Unfair Discrimination Act no 4 of 2000. Pretoria: Department of Justice. (Pamphlet).

Fataar, A. n.d. Higher education policy in South Africa: a struggle for alignment with macro-transformation policy. Paper presented at the Education Staff Seminar, 15 October 2002. University of the Western Cape, Bellville.

Fester, Gertrude. 2006. Some preliminary thoughts on sexuality, citizenship and constitutions: are rights enough? Agenda 67: 100-11.

Fogelberg, Paul, Jeff Hearn, Lisa Husu, and Teija Mankkinen. 1999. Hard work in the academy: research and interventions on gender inequalities in higher education. Helsinki: Helsinki University Press.

Foucault, Michel. 1978. The history of sexuality. Vol. 1: An introduction. New York: Pantheon Books.

Gender Equity Unit. n.d. Prejudice Reduction and AntiHomophobia Focus Week, UWC. 15-19 May. Unpublished 
report, 2006.

Gender Policy Action Committee (GPAC): Terms of Reference. 1996. Bellville: University of the Western Cape. (Approved SUK 96/24).

Hames, Mary. 2006. Rights and realities: limits to women's rights and citizenship after 10 years of democracy in South Africa. Third World Quarterly 27 (7): 1313-27.

Hames, Mary. 2003. The women's movement and lesbian and gay struggles in South Africa. Feminist Africa 2. http://www.feministafrica.org/fa\%202/2level.html_Date accessed: 5 March 2007.

Hames, Mary, Nontle Beja, and Tumelo Kgosimmele. 2005. The impact of sexual harass- ment policies in South African universities: the University of the Western Cape. In Bennett, Jane. Ed. Killing a virus with stones? 151-95.

Hill, Robert J. 1995. Gay discourse in Adult Education: a critical review. Adult Education Quarterly 45 (3): 142-58.

Hooks, bell. 1994. Teaching to transgress: education as the practice of freedom. New York: Routledge.

Kraak, Andre. 2001. Policy ambiguity and slippage: higher education under the new state, 1994-2001. Pretoria: Human Sciences Research Council.

Labour Relations Act No. 66 of 1995. Government Notice 1877. Pretoria: Government Printer. 
Leck, Glorianne M. 200o. Heterosexual or Homosexual? Reconsidering binary narratives on sexual identities in urban schools. Education and Urban Society 32 (3): 324-48.

Lewis, Desiree. 2003. Editorial. Feminist Africa 2: 1-7.

Lugg, Catherine A. 2003. Sissies, Faggots, Lezzies, and Dykes: gender, sexual orientation, and a new politics of education. Educational Administration Quarterly 39 (1): 95- 134.

---. 1998. The Religious Right and Public Education: The Paranoid Politics of Homophobia. Educational Policy 12 (3): 267-83.

Macgillivary, Ian K. 2000. Educational Equity for Gay, Lesbian, Bisexual, Transgendered and Queer/Questioning Students. The Demands of Democracy and Social Justice for America's Schools. Education and Urban Society 32 (3): 303-23.

Marshall, C. Ed. 1997. Feminist critical policy analysis: A perspective from primary and secondary schooling. London: Falmer Press.

Meintjes, Sheila. 2005. Gender equality by design: The case of South Africa's Commission on Gender Equality. Politkon 32 (2): 259-75.

Mission Statement. University Calendar 2007. Bellville: University of the Western Cape.

Morley, Louise. 2005. Opportunity or exploitation? Women and quality assurance in higher education. Gender and Education 17 (4): 411-29. 
Müller, U. 2000. Gender equality programmes in German institutions of higher education the north Rhine-Westphalia case. Higher Education in Europe 25 (2): 155-62. National Plan for Higher Education. 2001. Pretoria: Department of Education.

Oswin, Natalie. 2005. Researching 'Gay Cape Town', finding value-added queerness. Social \& Cultural Geography 6 (4): 57686.

Policy and Procedure on Sexual Harassment. 1995. Bellville: University of the Western Cape. Promotion of Equality and Prevention of Unfair Discrimination Act (Act 4 of 2000). Race settlement confirmed by equality court. 2004 . http://www.gmax.co.za/looko4/o2/11-SAequalitycourt.html Date accessed: 22 October 2006.

Reddy, V. 2002. Perverts and sodomites: homophobia as hate speech in Africa. Southern African Linguistics and Applied Language Studies 20 (3): 163-75.

Sanelli, Maria and George Perreault. 2001. 'I Could Be Anybody': Gay, lesbian and bisexual students in the U.S. schools. NASSP Bulletin 85 (622): 69-78.

Shaw, Kathleen M. 2004. Using feminist critical policy analysis in the realm of higher education: the case of welfare reform as gendered educational policy. The Journal of Higher Education 75 (1): 56-79.

Smulders, Anna E. M. 1998. Creating space for women: genderlinked factors in managing staff in higher education institutions. Paris: UNESCO: International Institute for Educational 
Planning.

Towards a new higher education landscape: meeting the equity, equality and social development imperatives of South Africa in the 21st century. 2000. Pretoria: Department of Education.

Unterhalter, Elaine. 2000. Remembering and forgetting: constructions of education gen- der reform in autobiography and policy texts of South African transition. History of Education 29 (5): 457-72.

Walker, Melanie. 1997. Women in the academy: ambiguity and complexity in a South African university. Gender and Education 9 (3): $365-81$.

Walsh, Val. 2002. Equal opportunities without 'equality': redeeming the irredeemable. In Gillian Howie and Ashley Tauchert. Eds. Gender, teaching and research in higher education: challenges for the 21st century. Aldershot: Ashgate, $33-45$. 